\title{
ANTIMICROBIAL RESISTANCE OF YERSINIA ENTEROCOLITICA IN DIFFERENT FOODS. A REVIEW
}

\author{
MILAD TAVASSOLI ${ }^{1}$, ASMA AFSHARI ${ }^{1}$, DOINA DRĂGĂNESCU ${ }^{2}$, ANDREEA LETIȚIA \\ ARSENE $^{3}$, TATYANA I. BURYKINA ${ }^{4}$, RAMIN REZAEE $^{5 *}$ \\ ${ }^{I}$ Department of Nutrition, Faculty of Medicine, Mashhad University of Medical Sciences, Mashhad, Iran \\ ${ }^{2}$ Department of Pharmaceutical Physics and Informatics, Faculty of Pharmacy, "Carol Davila" University of Medicine and \\ Pharmacy, 6 Traian Vuia Street, 020956, Bucharest, Romania \\ ${ }^{3}$ Department of General and Pharmaceutical Microbiology, Faculty of Pharmacy, "Carol Davila" University of Medicine \\ and Pharmacy, 6 Traian Vuia Street, 020956, Bucharest, Romania \\ ${ }^{4}$ Department of Analytical and Forensic Medical Toxicology, Sechenov University, 2-4 Bolshaya Pirogovskaya Street, \\ 119991 Moscow, Russia \\ ${ }^{5}$ Clinical Research Unit, Faculty of Medicine, Mashhad University of Medical Sciences, Mashhad, Iran
}

*corresponding author: raminrezaee1983@gmail.com

Manuscript received: December 2017

\begin{abstract}
Emergence of multidrug-resistant pathogens has become an important issue in the treatment of infectious diseases and poisonings. Unfortunately, the irrational use of antibiotics has rendered some pathogens resistant towards anti-microbial agents. Today, infections caused by antibiotic-resistant strains are difficult to treat. Yersinia is a bacterium that causes many diseases in humans. Since pigs are the main source of this bacterium, extensive research has been done on pork products compared to other foods, though the presence of Yersinia in other foods have also been reported. For the treatment of acute gastroenteritis, as one of the most common symptoms of bacterial infections, several antibiotics are prescribed. Three species of Yersinia from the Enterobacteriaceae family, are human pathogens and Y. enterocolitica is known as the most prevalent one. This review discusses the antimicrobial resistance pattern of $Y$. enterocolitica in different foods, based on the reports published from 1977 to 2018 .
\end{abstract}

\section{Rezumat}

Apariția agenților patogeni rezistenți la mai multe medicamente a devenit o problemă importantă în tratamentul bolilor infecțioase și intoxicațiilor. Din păcate, utilizarea irațională a antibioticelor a făcut ca anumiți agenți patogeni să fie rezistenți la substanțele antimicrobiene. Astăzi, infecțiile cauzate de tulpini rezistente la antibiotice sunt dificil de tratat. Yersinia este o bacterie care provoacă multe boli la om. Deoarece porcii sunt principala sursă a acestei bacterii, s-au făcut cercetări ample cu privire la produsele din carne de porc, în comparație cu alte alimente, deși prezența Yersinia în alte alimente a fost de asemenea raportată. Pentru tratamentul gastroenteritelor acute, ca unul dintre cele mai frecvente simptome ale infecțiilor bacteriene, sunt prescrise mai multe antibiotice. Trei specii de Yersinia din familia Enterobacteriaceae sunt agenți patogeni umani și Y. enterocolitica este cunoscută ca cea mai răspândită. Acest review analizează modelul de rezistență antimicrobiană la Y. enterocolitica în diferite alimente, pe baza rapoartelor publicate între anii 1977 și 2018.

Keywords: Antimicrobial resistance, Yersinia enterocolitica, foods, microbial resistance, Enterobacteriaceae

\section{Introduction}

Contamination with Yersinia enterocolitica can cause a variety of diseases, but mainly affects the digestive system. Y. enterocolitica causes pseudoappendicitis leading to unnecessary surgeries. Thus, monitoring microbial contamination along with proper administration of anti-microbial agents for treatment of infectious diseases, is of crucial importance [1]. Yersinia bacteria are non-spore forming, Gramnegative, rod-shaped or coccoid cells $(0.5-0.8 \mu \mathrm{m}$ wide and $1-3 \mu \mathrm{m}$ long) which exert bacterial motion (expect for Yersinia pestis) at $22-30^{\circ} \mathrm{C}$ but not at $37^{\circ} \mathrm{C}$. Their motility is due to the existence of the peritrichous flagella. Yersinia can be cultured in non-selective and certain selective media in aerobic and anaerobic environments, at temperatures ranging from 0 to $45^{\circ} \mathrm{C}$ with the best growth observed at 25 $28^{\circ} \mathrm{C}$ [2]. It has been reported that the use of antimicrobial agents in animal agriculture has remarkably enhanced the prevalence of zoonotic pathogens [3]. An increasing trend is observed in antimicrobialresistance prevalence among $Y$. enterocolitica strains $[4,5] Y$. enterocolitica as a main foodborne enteropathogen, causes different clinical presentations ranging from mild gastroenteritis to serious complications such as conjunctivitis and lymphadenitis [6]. Epidemiological studies have emphasized on the importance of detection of virulence genes in parallel with evaluation of antibiotic resistance. The genes 
that are mainly responsible for the virulence of $Y$. enterocolitica isolates are ail, inv and ist. Also, pYV which is a $70 \mathrm{~kb}$ plasmid, may carry virulence factors [7]. Compared to other Yersinia species, $Y$. enterocolitica more frequently causes disease in humans and animals. $Y$. enterocolitica species are categorized into six biotypes from which 1B, 2, 3, 4 and 5 are disease-causing biotypes in humans and animals, while biotype $1 \mathrm{~A}$ species are primarily not pathogenic [8]. Since $Y$. enterocolitica can easily grow in foods stored at room and cold temperatures, it can survive longer in rancid foods due to availability of increased levels of nutrients. Indeed, yersinosis is currently the third and largest food-borne zoonotic infection across Europe, as 8000 cases of yersinosis have been reported so far [9]. Nowadays, high levels of antimicrobial chemicals are used for the treatment of infected animals, prevention in case of disease outbreaks and enhancement of animals' growth and food consumption. Globally, it is accepted that increased resistance towards antibiotics correlates well with inappropriate administration of these agents to animals (for production or veterinary care) and humans [10]. The consequence is the transmission of antibiotic-resistant strains to foods and subsequently to humans [11]. It is assumed that, by 2050, approximately 10 million deaths may annually occur due to antimicrobial resistance, with an overall economic burden of $\$ 100$ trillion [12]. Following exposure of animals' pathogens to antibiotics, they may become resistant towards these agents and transmitted to humans while carrying resistance genes. This transfer from one species to another may take place through food, direct contact when resources (e.g. water) are mutually used [12]. Although yersinosis is seldom treated with anti-microbials, immunodeficient individuals need medication. Since $Y$. enterocolitica produces $\beta$-lactamase, it exerts resistance towards $\beta$-lactam antibiotics (e.g. ampicillin, carbenicillin, penicillin and first-generation cephalosporins) [13, 14]. Moreover, $Y$. enterocolitica has an internal resistance towards antibiotics such as ampicillin, ticarcillin, amoxicillin/ clavulanic acid, cefazolin and cephalothin [8]. The resistance of $Y$. enterocolitica towards antibiotics is at least in part, induced by $\beta$ lactamases-encoding genes, blaA and blaB. There is an alarming growing prevalence of $Y$. enterocolitica strains that show resistance towards antibiotics, including the multidrug-resistant $Y$. enterocolitica strains [15]. Nevertheless, fluoroquinolones and third- generation cephalosporins, are considered the most effective choices for treatment of enterocolitis in immunodeficient hosts and in patients with septicaemia or invasive infections, where the mortality rate may reach $50 \%$ [4].

The aim of this literature review was to evaluate the antimicrobial susceptibility of $Y$. enterocolitica isolated from different foods and investigate the pattern of $Y$. enterocolitica resistance towards various antibiotics based on the reports published between 1977 and 2018.

\section{Methods}

\section{Search strategy}

Scientific databases including ScienceDirect, Scopus, PubMed, SID and Google Scholar were searched for studies published between 1 January 1977 and 28 February 2018. In this literature search, we used the following combination of keywords: ("Antibiotic" or "Antibiogram") and ("Yersinia" or "Yersinia enterocolitica") and "Food" in the "title" and "abstract" of the articles. Duplicate publications, irrelevant topics and book chapters were excluded and were not further evaluated.

\section{Results and discussion}

Antimicrobial resistance of $Y$. enterocolitica in pigs A total 22 of articles, evaluating Y. enterocolitica antibiotic resistance in pigs as the main source of Yersinia, were found (Table I). According to these studies, $Y$. enterocolitica isolated from pigs has the highest level of sensitivity towards cefotaxime, ciprofloxacin, chloramphenicol, streptomycin, sulphonamide, tetracycline, gentamicin, trimethoprim and trimethoprim-sulfamethoxazole, while exhibited the highest levels of resistance towards ampicillin, ticarcillin, clindamycin and amoxicillin [16-21]. Variable antimicrobial susceptibility for $Y$. enterocolitica was reported towards nalidixic acid [16, 19, 21-23]. Noteworthy, pigs play an important role in $Y$. enterocolitica epidemiology and these asymptomatic carriers are considered the source of human enteropathogenic $Y$. enterocolitica, particularly bioserotype 4/O:3 [5, 24-26]. In a research conducted by Novoslavskij et al, all tested $Y$. enterocolitica 4/O:3 strains exhibited resistance to ampicillin and erythromycin and susceptibility to ciprofloxacin. Among the studied strains, 5\% were resistant to tetracycline and streptomycin [5]. 
Resistance toward antimicrobials among different strains of $Y$. enterocolitica in pork and pigs

\begin{tabular}{|c|c|c|c|c|c|}
\hline Strains & $\begin{array}{c}\text { Antibiotic to which the strains were } \\
\text { resistant }\end{array}$ & $\begin{array}{l}\text { Antibiotic to which the strains } \\
\text { were sensitive }\end{array}$ & Place & Year & Ref. \\
\hline Al1* & $\begin{array}{l}\text { amoxicillin, ampicillin, neomycin, } \\
\text { streptomycin, imipenem, sulfamethoxazole, } \\
\text { vancomycin, nitroimidazole, nalidixic acid, } \\
\text { florfenicol and tiamulin }\end{array}$ & $\begin{array}{l}\text { ciprofloxacin, kanamycin, } \\
\text { gentamicin, rifampicin, } \\
\text { tetracycline and chloramphenicol }\end{array}$ & Brazil & 2018 & {$[48]$} \\
\hline 3 variant $/ O: 3$ & $\begin{array}{l}\text { nalidixic acid, ampicillin , ticarcillin, } \\
\text { tetracycline, clindamycin and amoxicillin }\end{array}$ & - & & & \\
\hline 1B/O: 8 & clindamycin & - & & & \\
\hline $1 \mathrm{~A} / \mathrm{O}: 5$ & $\begin{array}{l}\text { ampicillin ticarcillin, amoxicillinand } \\
\text { clindamycin }\end{array}$ & - & Malaysia & 2017 & {$[16]$} \\
\hline All* & $\begin{array}{l}\text { nalidixic acid, clindamycin, ampicillin, } \\
\text { ticarcillin, tetracycline and amoxicillin }\end{array}$ & - & & & \\
\hline Al1* & $\begin{array}{c}\text { ampicillin }(100 \%) \text {, sulphonamides }(98.2 \%) \\
\text { and streptomycin }(78.2 \%)\end{array}$ & $\begin{array}{l}\text { amoxicillin-clavulanic acid, } \\
\text { gentamicin, ceftazidime, } \\
\text { ertapenem and meropenem, } \\
94.5 \% \text { to cefotaxime, } 89.1 \% \text { to } \\
\text { kanamycin and } 78.2 \% \text { to } \\
\text { tetracycline }\end{array}$ & $\begin{array}{l}\text { Northern } \\
\text { Italy }\end{array}$ & 2016 & {$[17]$} \\
\hline 4/O: 3 & cephalothin and ampicillin & - & & & \\
\hline 2/O: 9 & cephalothin and ampicillin & - & & & \\
\hline All* & $\begin{array}{c}\text { cephalothin }(92 \%) \text {, ampicillin }(89 \%) \text { and } \\
\text { amoxicillin/clavulanic acid }(8 \%)\end{array}$ & $\begin{array}{l}\text { ciprofloxacin, ceftazidime, } \\
\text { cefotaxime, chloramphenicol, } \\
\text { enrofloxacin, gentamicin, } \\
\text { kanamycin and neomycin }\end{array}$ & Italy & 2013 & {$[18]$} \\
\hline All* & $\begin{array}{c}\text { amoxicillin-clavulanic acid, ampicillin and } \\
\text { erythromycin }\end{array}$ & $\begin{array}{l}\text { cefotaxime, ciprofloxacin, } \\
\text { chloramphenicol, nalidixic acid, } \\
\text { streptomycin, sulphonamide, } \\
\text { tetracycline, trimethoprim and } \\
\text { trimethoprim-sulfamethoxazole }\end{array}$ & Italy & 2010 & {$[19]$} \\
\hline $4 / \mathrm{O}: 3$ & $\begin{array}{l}\text { ampicillin, cephalothin, erythromycin, } \\
\text { streptomycin, sulfamethoxazole, and } \\
\text { tetracycline }\end{array}$ & $\begin{array}{l}\text { amoxicillin-clavulanic acid, } \\
\text { aztreonam, cefotaxime, } \\
\text { ceftriaxone, chloramphenicol, } \\
\text { ciprofloxacin, nalidixic acid, } \\
\text { trimethoprim and trimethoprim- } \\
\text { sulfamethoxazole }\end{array}$ & Latvia & 2010 & {$[23]$} \\
\hline All* & ampicillin and sulfamethoxazole & $\begin{array}{l}\text { ciprofloxacin, nalidixic acid, } \\
\text { gentamicin, ceftiofur, tetracycline, } \\
\text { kanamycin, cefotaxime and } \\
\text { chloramphenicol }\end{array}$ & Germany & 2010 & {$[22]$} \\
\hline All* & ( & $\begin{array}{l}\text { amoxicillin/clavulanic acid, } \\
\text { ampicillin, ceftriaxone, } \\
\text { cefuroxime, chloramphenicol, } \\
\text { ciprofloxacin, gentamicin, } \\
\text { kanamycin, neomycin, } \\
\text { polymyxin, streptomycin, } \\
\text { tetracycline, trimethoprim, } \\
\text { trimethoprim/sulfamethoxazole, } \\
\text { and sulphonamide }\end{array}$ & Switzerland & 2007 & {$[20]$} \\
\hline $\mathrm{O}: 3$ & $\begin{array}{l}\text { tetracycline, gentamicin, kanamycin, } \\
\text { sulphonamides, nalidixic acid, trimethoprim, } \\
\text { and streptomycin }\end{array}$ & ( & Austria & 2004 & {$[21]$} \\
\hline $4 / \mathrm{O}: 3$ & ampicillin and erythromycin & ciprofloxacin & Lithuania** $^{*}$ & 2012 & {$[5]$} \\
\hline
\end{tabular}

*All: All strains of Yersinia enterocolitica, ** Study of pigs and humans

Antimicrobial resistance of $Y$. enterocolitica found in meats

Meat and meat products as the main sources of foodborne infectious diseases are crucial parts of the chain from food-producing animals to humans [21]. For growth enhancement as well as prevention and treatment of infections, antimicrobial agents have been efficaciously administered to poultry. But, the afore mentioned application has led to increased bacterial resistance to many antibiotics [27, 28]. Y. enterocolitica isolated from meat and meat products [11] showed the highest resistance to clindamycin, 
cephalothin, ampicillin, trimethoprim, amoxicillin, ciprofloxacin, streptomycin and tetracycline while exhibited sensitivity to tobramycin, imipenem, gentamicin, chloramphenicol, cefotaxime, sulphonamide and sulfamethoxazole.[19, 21]Y. enterocolitica has shown different reactions towards some antibiotics that are further discussed in the conclusion section [27-29]. Some reports from Brazil, Northern Italy, Latvia and Australia, showed resistance of $Y$. enterocolitica isolated from pigs to streptomycin, but susceptibility was shown in reports from Italy and Switzerland.

Table II

Antimicrobial resistance pattern among Y. enterocolitica strains isolated from meats

\begin{tabular}{|c|c|c|c|c|c|}
\hline Strains & $\begin{array}{c}\text { Antibiotic to which the strains were } \\
\text { resistant }\end{array}$ & $\begin{array}{c}\text { Antibiotic to which the strains were } \\
\text { sensitive }\end{array}$ & Place & Year & Ref. \\
\hline All* & clindamycin & tobramycin and imipenem & Turkey & 2015 & [29] \\
\hline All* & $\begin{array}{l}\text { cephalothin, ampicillin, trimethoprim, } \\
\text { amoxicillin, ciprofloxacin, nalidixic acid, } \\
\text { streptomycin, tetracycline }\end{array}$ & gentamicin and chloramphenicol & Iran & 2013 & [59] \\
\hline All* & amoxicillin-clavulanic acid & $\begin{array}{l}\text { cefotaxime, ciprofloxacin, chloramphenicol, } \\
\text { nalidixic acid, streptomycin, sulphonamide, } \\
\text { tetracycline, trimethoprim, and trimethoprim- } \\
\text { sulfamethoxazole. }\end{array}$ & Italy & 2010 & [19] \\
\hline Al1* & cephalothin $(98 \%)$ and ampicillin $(52 \%)$ & ciprofloxacin $(95 \%)$ & Iran & 2009 & [11] \\
\hline All* & $\begin{array}{l}\text { tetracycline, gentamicin, kanamycin, } \\
\text { sulphonamides, nalidixic acid, } \\
\text { trimethoprim, chloramphenicol and } \\
\text { streptomycin }\end{array}$ & 1 & Austria & 2004 & [21] \\
\hline
\end{tabular}

Milk and dairy products are mainly contaminated with non-pathogenic isolates of $Y$. enterocolitica. Interestingly, contamination of such products with pathogenic strains is mostly linked with outbreaks of yersinosis [30]. Several dairy products, including raw and pasteurized milk, ice cream, cheese and cream were found to be contaminated with $Y$. enterocolitica and $Y$. enterocolitica-like organisms [31]. The most frequently found species in dairy products were $Y$. enterocolitica biotype 1A, Yersinia intermedia and Yersinia frederiksenii [32, 33].
However, since pathogenic form of $Y$. enterocolitica can grow at refrigeration temperatures $\left(0-4^{\circ} \mathrm{C}\right)$, the presence of this form of $Y$. enterocolitica in milk is highly possible, which renders it a matter of health concern for dairy producers [31]. Y. enterocolitica isolated from milk and dairy products had the highest resistance to tetracycline, cephalothin, ampicillin, streptomycin, amoxicillin, nalidixic acid and clindamycin, but were sensitive to chloramphenicol and ciprofloxacin $[29,34]$.

Table III

Antimicrobial resistance pattern among $Y$. enterocolitica strains in dairy products

\begin{tabular}{|c|c|c|c|c|c|}
\hline Strains & Antibiotic to which the strains were resistant & $\begin{array}{c}\text { Antibiotic to which the strains were } \\
\text { sensitive }\end{array}$ & Place & Year & Ref. \\
\hline All* & $\begin{array}{l}\text { amoxicillin, cefoxitin, cephalexin and amoxicillin - } \\
\text { clavulanic acid }\end{array}$ & $\begin{array}{l}\text { tetracycline, ticarcillin, ciprofloxacin, } \\
\text { nalidixic acid, ceftriaxone, } \\
\text { trimethoprim and sulfamethoxazole }\end{array}$ & Italy & 2018 & [49] \\
\hline All* & $\begin{array}{c}\text { tetracycline }(48.3 \%) \text {, followed by ciprofloxacin and } \\
\text { cephalothin }(\text { each } 17.2 \%) \text {, ampicillin }(13.8 \%) \text {, } \\
\text { streptomycin }(6.9 \%) \text {, and amoxicillin and nalidixic } \\
\text { acid (each } 3.4 \%) \text {. }\end{array}$ & gentamicin and chloramphenicol & Iran & 2015 & [34] \\
\hline All* & clindamycin & tobramycin and imipenem & Turkey & 2015 & [29] \\
\hline
\end{tabular}

\begin{abstract}
Antimicrobial resistance of $Y$. enterocolitica detected in fruits and vegetables

Fruits, vegetables and their products are regarded as potential carriers of $Y$. enterocolitica [35]. Although, $Y$. enterocolitica might be potentially transmitted via consumption of fruits and vegetables [36], few studies have evaluated the existence of pathogenic and non-pathogenic $Y$. enterocolitica and other Yersinia spp. in fruits, vegetables and related products.
\end{abstract}

Furthermore, the growing trend of antibiotic resistance necessitates investigation of resistance to antimicrobials among bacteria detected in food products [6]. Studies in fruits and vegetables showed that $Y$. enterocolitica isolated from these products had the highest resistance to ampicillin, erythromycin, amoxicillin/clavulanic acid, streptomycin, cephalothin and carbenicillin but were susceptible to ciprofloxacin, gentamicin, enrofloxacin, cefotaxime, imipenem, 
meropenem, tobramycin, colistin, trimethoprim, sulfamethoxazole, nalidixic acid, tetracycline,

chloramphenicol and kanamycin $[6,36]$.

Table IV

Antimicrobial resistance pattern among $Y$. enterocolitica strains isolated from fruits and vegetables

\begin{tabular}{|c|c|c|c|c|c|}
\hline Strains & $\begin{array}{c}\text { Antibiotic to which the strains were } \\
\text { resistant }\end{array}$ & $\begin{array}{l}\text { Antibiotic to which the strains were } \\
\text { sensitive }\end{array}$ & Place & Year & Ref. \\
\hline All* & $\begin{array}{l}\text { ampicillin }(100 \%), \text { followed by erythromycin } \\
(98.1 \%), \text { amoxicillin/clavulanic acid } \\
(77.4 \%) \text { and streptomycin }(39.6 \%)\end{array}$ & $\begin{array}{l}\text { ciprofloxacin, gentamicin, enrofloxacin, } \\
\text { cefotaxime, imipenem, meropenem, } \\
\text { tobramycin, colistin, trimethoprim and } \\
\text { trimethoprim-sulfamethoxazole }\end{array}$ & $\begin{array}{l}\text { European } \\
\text { Union }\end{array}$ & 2017 & [6] \\
\hline All* & $\begin{array}{l}\text { ampicillin } \\
\text { cephalothin } \\
\text { carbenicillin }\end{array}$ & $\begin{array}{l}\text { nalidixic acid, streptomycin, tetracycline, } \\
\text { tobramycin, chloramphenicol, kanamycin, } \\
\text { gentamicin, trimethoprim and ciprofloxacin }\end{array}$ & Korea & 2004 & [36] \\
\hline
\end{tabular}

*All: All strains of Yersinia enterocolitica

Antimicrobial resistance of $Y$. enterocolitica detected in frozen foods

Without causing evident decomposition in frozen food products, $Y$. enterocolitica can stay alive at low temperatures [15]. In this regard, Ye et al showed that all strains isolated from frozen products were sensitive to ticarcillin but they were resistant to two or more antibiotics, and $48.6 \%$ of the strains were resistant to four to nine antibiotics. Resistance rates of $98.6,95.7,74.3,28.6,18.6$ and $12.9 \%$, were observed for ampicillin, cephalothin, trimethoprim/ sulfamethoxazole, amoxicillin/clavulanic acid, nalidixic acid and chloramphenicol, respectively [15].

Antimicrobial resistance pattern among $Y$. enterocolitica strains isolated from frozen foods

\begin{tabular}{|c|c|c|c|c|c|}
\hline Strains & Antibiotic to which the strains were resistant & $\begin{array}{l}\text { Antibiotic to which the } \\
\text { strains were sensitive }\end{array}$ & Place & Year & Ref. \\
\hline All* & $\begin{array}{l}\text { ampicillin, cephalothin, trimethoprim-sulfamethoxazole, } \\
\text { amoxicillin/clavulanic acid, nalidixic acid and chloramphenicol }\end{array}$ & ticarcillin & China & 2015 & [15] \\
\hline
\end{tabular}

*All: All strains of Yersinia enterocolitica

Antimicrobial resistance $Y$. enterocolitica found in retail seafood

In a study that evaluated resistance pattern in seafood-borne $Y$. enterocolitica strains, all isolates were sensitive to cefotaxime, cefuroxime, chloramphenicol, ciprofloxacin, gentamicin, kanamycin, nalidixic acid, streptomycin, tetracycline and trimethoprim. However, these isolates were resistant towards cephalothin (83.3\% of isolates), amoxicillin (83.3\%), and ampicillin $(50.0 \%)[37]$.

Table VI

Antimicrobial resistance pattern among $Y$. enterocolitica strains isolated from retail seafood

\begin{tabular}{|c|c|c|c|c|c|}
\hline Strains & $\begin{array}{c}\text { Antibiotic to which the strains were } \\
\text { resistant }\end{array}$ & Antibiotic to which the strains were sensitive & Place & Year & Ref. \\
\hline All* & $\begin{array}{c}\text { cephalothin, } \\
\text { amoxicillin, } \\
\text { ampicillin }\end{array}$ & $\begin{array}{l}\text { cefotaxime, cefuroxime, chloramphenicol, } \\
\text { ciprofloxacin, gentamicin, kanamycin, nalidixic } \\
\text { acid, streptomycin, tetracycline, and trimethoprim }\end{array}$ & Germany & 2018 & [37] \\
\hline
\end{tabular}

*All: All strains of Yersinia enterocolitica

Antimicrobial resistance of Yersinia enterocolitica strains obtained from foods and humans

A small number of $57 \mathrm{O}$ serogroups are regarded as humans and animals pathogens. Globally, strains that belong to serogroups $\mathrm{O}: 3$ (biogroup 4), O:5,27 (biogroups 2 and 3), O:8 (biogroup 1B) and O:9 (biogroup 2), are the ones that are most commonly isolated from human samples [4, 38]. Nevertheless, in Europe, $Y$. enterocolitica serogroups O:3 and O:9 are of crucial importance while in the United States, serogroup O:8 has raised concerns [4]. In a study, Lucero-Estrada $\mathrm{C}$ et al found all the $Y$. enterocolitica strains isolated susceptible to amikacin, aztreonam, cefuroxime, ciprofloxacin, chloramphenicol, colistin, fosfomycin, furazolidone, gentamicin, kanamycin, nalidixic acid, neomycin, tetracycline and trimethoprimsulfamethoxazole, but resistant to ampicillin, cephalothin, erythromycin and rifampicin [39].

Table VII

Antimicrobial resistance pattern among Yersinia enterocolitica strains isolated from foods and humans

\begin{tabular}{|c|c|c|c|c|c|c|}
\hline \multicolumn{2}{|c|}{ Strains } & \multirow{2}{*}{$\begin{array}{l}\text { Antibiotic to which the } \\
\text { strains were resistant } \\
\text { ampicillin, cephalothin, } \\
\text { erythromycin and } \\
\text { rifampicin }\end{array}$} & \multirow{2}{*}{$\begin{array}{l}\text { Antibiotic to which the strains were sensitive } \\
\text { amikacin, aztreonam, cefuroxime, ciprofloxacin, } \\
\text { chloramphenicol, colistin, fosfomycin, furazolidone, } \\
\text { gentamicin, kanamycin, nalidixic acid, neomycin, } \\
\text { tetracycline and trimethoprim-sulfamethoxazole }\end{array}$} & \multirow{2}{*}{$\begin{array}{c}\text { Place } \\
\text { Argentina }\end{array}$} & \multirow{2}{*}{$\begin{array}{l}\text { Year } \\
2015\end{array}$} & \multirow{2}{*}{$\begin{array}{l}\text { Ref. } \\
{[39]}\end{array}$} \\
\hline $\begin{array}{c}\text { Food } \\
\text { samples } \\
\text { Clinical } \\
\text { samples }\end{array}$ & $2,3,1 \mathrm{~A}$ & & & & & \\
\hline
\end{tabular}


Different food-borne serotypes of $Y$. enterocolitica show various responses to antibiotics; for instance in Malaysia, $1 \mathrm{~B} / \mathrm{O}: 8$ strain was resistant to only one antibiotic (i.e. clindamycin) but $\mathrm{O}: 3$ and 1A/O:5 serotypes were resistant to clindamycin, nalidixic acid, ampicillin, ticarcillin, tetracycline and amoxicillinclavulanic acid [16]. These finding should be considered when choosing treatments strategies against different strains of $Y$. enterocolitica. Several studies showed that $Y$. enterocolitica was resistant to clindamycin [15, 40-45]. In some studies, the greatest resistance rate was seen against ampicillin and amoxicillin [10, 46-49]. Resistance to ampicillin was observed in all of the reviewed studies including with the reports from Switzerland, Germany and the United Kingdom [20, 22, 50]. In contrast, in samples collected from the USA in 2006 and Prince Edward Island in 1995, only 87 and $77 \%$ of $Y$. enterocolitica isolates were resistant to ampicillin, respectively [51-53]. High resistance rate of $Y$. enterocolitica towards ampicillin and cephalothin has been widely reported by different studies [15, 54-56]. Sensitivity of $Y$. enterocolitica to amoxicillin varied among different studies as it showed sensitivity in northern Italy, Switzerland, southern Germany and the United States [46, 57, 58] while exhibited resistance in studies conducted in Brazil [48], Germany [59], China [15], Italy [19], Iran and Malaysia [16, 34, 37].

In studies conducted in the United States, Switzerland and Germany, sensitivity to ciprofloxacin, gentamicin, enrofloxacin, cefotaxime, imipenem, meropenem, tobramycin, colistin, trimethoprim and trimethoprim/ sulfamethoxazole, were more commonly observed compared to other antibiotics [46, 57, 58, 60]. Y. enterocolitica showed susceptibility to some aminoglycoside antibiotics (including amikacin, neomycin, kanamycin and gentamicin), as well as colistin and cefuroxime [20, 39, 56, 61, 62].

$Y$. enterocolitica was found to be resistant to macrolide antibiotics such as erythromycin $[5,6,19$, 23, 39]. Additionally, the highest rate of resistance was reported for sulphonamides in the United States and Germany [60, 63]. Also, Y. enterocolitica was more sensitive to sulfamethoxazole in samples collected form the European Union (EU) member states, but a report from Germany detected resistance to sulfamethoxazole in three (2\%) 4/O:3 strains as also reported by a Chinese study. These data showed variability among results obtained by studies done in the EU countries [6, 15, 19, 20,60]. Some studies found resistance to streptomycin in most of the strains, as shown by the studies performed in the EU, Iran, Latvia [6, 17, 21, 23, 34]; however, there are reports from Germany, Iran, Italy, Switzerland and Korea that showed sensitivity of $Y$. enterocolitica towards streptomycin. These studies showed that resistance pattern towards streptomycin has changed over the years in the EU and Asia [19, 20, 36, 37, 59].

Although since 1994, administration of chloramphenicol to food-producing animals has been prohibited in the EU, a report from Austria and another report from a non-EU country (i.e. China) showed that up to $60 \%$ of $Y$. enterocolitica strains were resistant to chloramphenicol [10, 15, 21, 53]. Conversely, studies done in Brazil, Switzerland, Germany, Argentina, Iran, Korea and Italy reported sensitivity to chloramphenicol [19-21, 34, 36, 37, 39, 48, 59, 64].

For tetracycline, resistance was reported from Malaysia, Iran and Austria [16, 21, 59], but sensitivity was found in studies done in Brazil, Argentina, Germany, Korea, Switzerland, Italy and north Italy $[17,19,20$, $36,37,39,48]$.

In reports from the EU countries, Korea and Iran, $Y$. enterocolitica was mostly sensitive to trimethoprimsulfamethoxazole $[6,11,20,36,49,55,56,65]$ while resistance was reported by studies done in Ireland and Germany $[55,65]$.

Resistance towards ticarcillin was investigated by a few studies; reports from China and Italy found $Y$. enterocolitica susceptible to ticarcillin while resistance was showed by a report from Malaysia [15, 16, 49]. Most studies found $Y$. enterocolitica sensitive towards ciprofloxacin $[5,6,11,19,20,22,23,37,39,48,49$, 56, 62]; but, an Iranian report published in 2009, showed that $Y$. enterocolitica was sensitive to ciprofloxacin, while it was found resistant in studies performed during 2013 and 2014, indicating the possibility of changes in resistance pattern of $Y$. enterocolitica to ciprofloxacin in Iran $[11,34,59]$. Concerning nalidixic acid, studies done in Brazil, Malaysia, Australia, China and Iran, found $Y$. enterocolitica resistant, while it was reported to be sensitive by research in Germany, Korea, Argentina, Latvia and Italy $[15,16,19,21-23,34,36,37,39$, 48, 49].

The anti-microbial resistance/sensitivity pattern of $Y$. enterocolitica was studied in different types of foods. All $Y$. enterocolitica isolated from different foods were resistant to three antibiotics namely, ampicillin, amoxicillin and cephalothin. Y. enterocolitica isolated from fruits and vegetables [15, 36], dairy [49, 59] products and retail seafood [37] were sensitive to nalidixic acid; however, stains isolated from frozen food and meat products were resistant. $Y$. enterocolitica isolated from dairy products and frozen food were sensitive to ticarcillin $[15,16,49]$. $Y$. enterocolitica isolated from different foods showed different reactions to streptomycin as those isolated from meat products in Iran and Australia, were resistant to streptomycin, while a study done in Italy showed sensitivity towards streptomycin $[19,21,59]$. In dairy products, fruits and vegetables collected from the EU countries, Y. enterocolitica was resistant to streptomycin, but sensitive in fruits 
FARMACIA, 2018, Vol. 66, 3

and vegetables samples collected form Korea and retail sea food samples in Germany [6, 34, 36, 37]. In terms of resistance towards sulfamethoxazole, $Y$. enterocolitica isolated from dairy products, meat and fruits and vegetables showed susceptibility [6, 19, 49]. Different reactions were observed following treatment of $Y$. enterocolitica isolated from different food, with tetracycline; $Y$. enterocolitica isolated from dairy products $[17,19,20]$, fruits and vegetables $[22,36,37]$ and retail sea food were sensitive [39, $48,49]$, while those isolated from dairy products in Iran were resistant [34].

With regard to resistance/sensitivity towards trimethoprim, $Y$. enterocolitica isolated from was meat products in Iran were susceptible but those isolated from frozen foods in China were resistant $[15,59]$.

\section{Conclusions}

The anti-microbial resistance pattern of $Y$. enterocolitica to different antibiotics were almost similar in most of the reviewed studies but antibiotics such as sulphonamides, chloramphenicol, tetracycline, trimethoprim-sulfamethoxazole, ciprofloxacin and nalidixic acid had inconsistent results. Studies showed that different strains of $Y$. enterocolitica have different reactions to the abovenoted antibiotics in different geographical regions. Therefore, it could be suggested that geographical region and type of food consumed, should be considered for choosing appropriate strategies for treatment of the $Y$. enterocolitica infections.

\section{References}

1. Kojima M, Morita Y, Shimizu K, Yoshida T, Yamada I, Togo T, Johshita T, Takashi, Immunohistological findings of suppurative granulomas of Yersinia enterocolitica appendicitis: A report of two cases. Pathol Res Pract., 2007; 203(2): 115-119.

2. Kerr J, Manual of Clinical Microbiology, 8th Edition. J Clin Pathol., 2004; 57(1): 111.

3. Hazem Abbas, Popescu CV, Crişan I, Popa M, Chifiriuc MC, Gradișteanu Pircalabioru G, Lupuliasa $\mathrm{D}$, Antibacterial efficiency of five propolis extracts on planktonic and adherent microbial strains. Farmacia, 2017; 65(5): 813-818.

4. Fabrega A, Vila J, Yersinia enterocolitica: pathogenesis, virulence and antimicrobial resistance. Enferm Infecc Microbiol Clin., 2012; 30(1): 24-32.

5. Novoslavskij A, Kudirkiene E, Marcinkute A, Bajoriuniene A, Korkeala H, Malakauskas M, Genetic diversity and antimicrobial resistance of Yersinia enterocolitica isolated from pigs and humans in Lithuania. J Sci Food Agric., 2013; 93(8): 1858-1862.

6. Verbikova V, Borilova G, Babak V, Moravkova M, Prevalence, characterization and antimicrobial susceptibility of Yersinia enterocolitica and other Yersinia species found in fruits and vegetables from the European Union. Food Control., 2018; 85: 161-167.
7. Yang X, Huang J, Wu Q, Zhang J, Liu S, Guo W, Cai Sh, Yu Sh, Prevalence, antimicrobial resistance and genetic diversity of Salmonella isolated from retail ready-to-eat foods in China. Food Control., 2016; 60: 50-56.

8. Frazao MR, Andrade LN, Darini ALC, Falcao JP, Antimicrobial resistance and plasmid replicons in Yersinia enterocolitica strains isolated in Brazil in 30 years. Braz J Infect Dis., 2017; 21(4): 477-480.

9. Coronel-León J, López A, Espuny MJ, Beltran MT, Molinos-Gómez A, Rocabayera X, Assessment of antimicrobial activity of Na-lauroyl arginate ethylester $\left(\mathrm{LAE}^{\circledR}\right)$ against Yersinia enterocolitica and Lactobacillus plantarum by flow cytometry and transmission electron microscopy. Food Control., 2016; 63: 1-10.

10. Aarestrup FM, Bager F, Jensen NE, Madsen M, Meyling A, Wegener HC, Resistance to antimicrobial agents used for animal therapy in pathogenic-, zoonotic- and indicator bacteria isolated from different food animals in Denmark: a baseline study for the Danish Integrated Antimicrobial Resistance Monitoring Programme (DANMAP). APMIS, 1998; 106(7-12): 745-770.

11. Dallal MMS, Doyle MP, Rezadehbashi M, Dabiri H, Sanaei M, Modarresi S, Bakhtiari R, Sharifiy K, Taremi M, Zali MR, Sharifi-Yazdi MK, Prevalence and antimicrobial resistance profiles of Salmonella serotypes, Campylobacter and Yersinia spp. isolated from retail chicken and beef, Tehran, Iran. Food Control., 2010; 21(4): 388-392.

12. Tang KL, Caffrey NP, Nóbrega DB, Cork SC, Ronksley PE, Barkema HW, Polachek AJ, Ganshorn H, Sharma N, Kellner JD, Ghali WA, Restricting the use of antibiotics in food-producing animals and its associations with antibiotic resistance in food-producing animals and human beings: a systematic review and meta-analysis. Lancet Planet Health, 2017; 1(8): e316-e327.

13. Stock I, Heisig P, Wiedemann B, Expression of $\beta$ lactamases in Yersinia enterocolitica strains of biovars 2, 4 and 5. JMed Microbiol., 1999; 48(11): 1023-1027.

14. Sihvonen LM, Toivonen S, Haukka K, Kuusi M, Skurnik M, Siitonen A, Multilocus variable-number tandem-repeat analysis, pulsed-field gel electrophoresis, and antimicrobial susceptibility patterns in discrimi-nation of sporadic and outbreak-related strains of Yersinia enterocolitica. BMC Microbiol., 2011; 11: 1-10.

15. Ye Q, Wu Q, Hu H, Zhang J, Huang H, Prevalence, antimicrobial resistance and genetic diversity of Yersinia enterocolitica isolated from retail frozen foods in China. FEMS Microbiol Lett., 2015; 362(24): 1-7.

16. Thong KL, Tan LK, Ooi PT, Genetic diversity, virulotyping and antimicrobial resistance susceptibility of Yersinia enterocolitica isolated from pigs and porcine products in Malaysia. J Sci Food Agric., 2018; 98(1): 87-95.

17. Bonardi S, Bruini I, D'Incau M, Van Damme I, Carniel E, Bremont S, Cavallini P,Tagliabue S, Brindani F, Detection, seroprevalence and antimicrobial resistance of Yersinia enterocolitica and Yersinia pseudotuberculosis in pig tonsils in Northern Italy. Int J Food Microbiol., 2016; 235: 125-132. 
FARMACIA, 2018, Vol. 66, 3

18. Bonardi S, Alpigiani I, Pongolini S, Morganti M, Tagliabue S, Bacci C, Brindani F, Detection, enumeration and characterization of Yersinia enterocolitica 4/O:3 in pig tonsils at slaughter in Northern Italy. Int J Food Microbiol., 2014; 177: 9-15.

19. Bonardi S, Paris A, Bassi L, Salmi F, Bacci C, Riboldi E, Boni E, D'Incau M, Tagliabue S, Brindani F, Detection, semiquantitative enumeration, and antimicrobial susceptibility of Yersinia enterocolitica in pork and chicken meats in Italy. $J$ Food Prot., 2010; 73(10): 1785-1792.

20. Baumgartner A, Kuffer M, Suter D, Jemmi T, Rohner P, Antimicrobial resistance of Yersinia enterocolitica strains from human patients, pigs and retail pork in Switzerland. Int J Food Microbiol., 2007; 115(1): 110-114.

21. Mayrhofer S, Paulsen P, Smulders FJM, Hilbert F, Antimicrobial resistance profile of five major foodborne pathogens isolated from beef, pork and poultry. Int J Food Microbiol., 2004; 97(1): 23-29.

22. von Altrock A, Roesler U, Merle R, Waldmann KH, Prevalence of pathogenic Yersinia enterocolitica strains on liver surfaces of pigs and their antimicrobial susceptibility. J Food Prot., 2010; 73(9): 1680-1683.

23. Terentjeva M, Berzins A, Prevalence and antimicrobial resistance of Yersinia enterocolitica and Yersinia pseudotuberculosis in slaughter pigs in Latvia. $J$ Food Prot., 2010; 73(7): 1335-1338.

24. Bottone EJ, Yersinia enterocolitica: overview and epidemiologic correlates. Microbes Infect., 1999; 1(4): 323-333.

25. Fredriksson-Ahomaa M, Stolle A, Siitonen A, Korkeala H, Sporadic human Yersinia enterocolitica infections caused by bioserotype 4/O:3 originate mainly from pigs. J Med Microbiol. 2006;55(6):747-9.

26. Fredriksson-Ahomaa M, Hallanvuo S, Korte $T$, Siitonen A, Korkeala H, Correspondence of genotypes of sporadic Yersinia enterocolitica bioserotype 4/O:3 strains from human and porcine sources. Epidemiol Infect., 2001; 127(1): 37-47.

27. Castanon JIR, History of the use of antibiotic as growth promoters in European poultry feeds. Poult Sci., 2007; 86(11): 2466-2471.

28. Mathew AG, Cissell R, Liamthong S, Antibiotic resistance in bacteria associated with food animals: A United States perspective of livestock production. Foodborne Pathog Dis., 2007; 4(2): 115-133.

29. Özdemir F, Arslan S, Genotypic and phenotypic virulence characteristics and antimicrobial resistance of Yersinia spp. isolated from meat and milk products. J Food Sci Technol., 2015; 80(6): M1306-M1313.

30. Ackers M-L, Schoenfeld S, Markman J, Smith MG, Nicholson MA, DeWitt W, Cameron D, N, Griffin PM, Slutsker L, An Outbreak of Yersinia enterocolitica O: 8 infections associated with pasteurized milk. $J$ Infect Dis., 2000; 181(5): 1834-1837.

31. Durisin MD, Ibrahim A, Griffiths MW, Detection of pathogenic Yersinia enterocolitica in milk and pork using a DIG-labelled probe targeted against the yst gene. Int J Food Microbiol., 1997; 37(2-3): 103-112.
32. Walker SJ, Gilmour A, The incidence of Yersinia enterocolitica and Yersinia enterocolitica like organisms in raw and pasteurized milk in Northern Ireland. J Appl Microbiol., 1986; 61(2): 133-138.

33. Hughes D, Isolation of Yersinia enterocolitica from milk and a dairy farm in Australia. $J$ Appl Microbiol., 1979; 46(1): 125-130.

34. Jamali H, Paydar M, Radmehr B, Ismail S. Prevalence, characterization, and antimicrobial resistance of Yersinia species and Yersinia enterocolitica isolated from raw milk in farm bulk tanks. $J$ Dairy Sci., 2015; 98(2): 798-803.

35. Losio MN, Pavoni E, Bilei S, Bertasi B, Bove D, Capuano F, Farneti S, Blasi G, Comin D, Cardamone C, Decastelli L, Delibato E, De Santis P, Di Pasquale S, Gattuso A, Goffredo E, Fadda A, Pisanu M, De Medici D, Microbiological survey of raw and ready-to-eat leafy green vegetables marketed in Italy. Int J Food Microbiol., 2015; 210: 88-91.

36. Lee TS, Lee SW, Seok WS, Yoo MY, Yoon JW, Park BK, Moon KD, Oh DH, Prevalence, antibiotic susceptibility, and virulence factors of Yersinia enterocolitica and related species from ready-to-eat vegetables available in Korea. J Food Prot., 2004; 67(6): 1123-1127.

37. Li C, Golz G, Alter T, Barac A, Hertwig S, Riedel $\mathrm{C}$, Prevalence and antimicrobial resistance of Yersinia enterocolitica in retail seafood. J Food Prot., 2018: 497-501.

38. Asplund K, Johansson T, Siitonen A, Evaluation of pulsed-field gel electrophoresis of genomic restriction fragments in the discrimination of Yersinia enterocolitica O[ratio]3. Epidemiol Infect., 1998; 121(3): 579-586.

39. Lucero-Estrada CS, Soria JM, Favier GI, Escudero ME, Evaluation of the pathogenic potential, antimicrobial susceptibility, and genomic relations of Yersinia enterocolitica strains from food and human origin. Can J Microbiol., 2015; 61(11): 851-860.

40. Carlson JR, Thornton SA, DuPont HL, West AH, Mathewson JJ, Comparative in vitro activities of ten antimicrobial agents against bacterial enteropathogens. Antimicrob Agents Chemother., 1983; 24(4): 509-13.

41. Kanazawa Y, Ikemura K, Kuramata T, Drug susceptibility of Yersinia enterocolitica and Yersinia pseudotuberculosis. Contrib Microbiol Immunol., 1987; 9: 127-135.

42. Kwaga J, Iversen JO, In vitro antimicrobial susceptibilities of Yersinia enterocolitica and related species isolated from slaughtered pigs and pork products. Antimicrob Agents Chemother., 1990; 34(12): 2423-2425.

43. Raevuori M, Harvey SM, Pickett MJ, Martin WJ, Yersinia enterocolitica: In vitro antimicrobial susceptibility. Antimicrob Agents Chemother., 1978; 13(5): 888-890.

44. Restaino L, Hill WM, Antibiotic susceptibility patterns of Yersinia enterocolitica. J Food Prot., 1981; 44(2): 124-127.

45. Preston MA, Brown S, Borczyk AA, Riley G, Krishnan C, Antimicrobial susceptibility of pathogenic Yersinia enterocolitica isolated in Canada from 
1972 to 1990. Antimicrob Agents Chemother., 1994; 38(9): 2121-2124.

46. Bhaduri S, Wesley I, Richards H, Draughon A, Wallace M, Clonality and antibiotic susceptibility of Yersinia enterocolitica isolated from U.S. market weight hogs. Foodborne Pathog Dis., 2009; 6(3): 351-356.

47. Falcão JP, Brocchi M, Proença-Módena JL, Acrani GO, Corrêa EF, Falcão DP, Virulence characteristics and epidemiology of Yersinia enterocolitica and Yersiniae other than $Y$. pseudotuberculosis and $Y$. pestis isolated from water and sewage. J Appl Microbiol., 2004; 96(6): 1230-1236.

48. Martins BTF, Botelho CV, Silva DAL, Lanna FGPA, Grossi JL, Campos-Galvão MEM, Yamatogi RS, Falcão JP, dos Santos Bersot L, Nero LA, Yersinia enterocolitica in a Brazilian pork production chain: Tracking of contamination routes, virulence and antimicrobial resistance. Int J Food Microbiol., 2018; 276: 5-9.

49. Bonardi S, Le Guern AS, Savin C, Pupillo G, Bolzoni L, Cavalca M, Pongolini S, Detection, virulence and antimicrobial resistance of Yersinia enterocolitica in bulk tank milk in Italy. Int Dairy J., 2018; 84: 46-53.

50. Lyons MM, Prentice MB, Cope D, Swann RA, Antimicrobial susceptibility of pathogenic Yersinia enterocolitica strains in the British Isles. Contrib Microbiol Immunol., 1991; 12: 251-254.

51. Abdel-Haq NM, Papadopol R, Asmar BI, Brown WJ, Antibiotic susceptibilities of Yersinia enterocolitica recovered from children over a 12 -year period. Int $J$ Antimicrob Agents., 27(5): 449-452.

52. Hariharan H, Giles JS, Heaney SB, Leclerc SM, Schurman RD, Isolation, serotypes, and virulenceassociated properties of Yersinia enterocolitica from the tonsils of slaughter hogs. Can J Vet., 1995; 59(3): 161-166.

53. Meyer C, Stolle A, Fredriksson-Ahomaa M, Comparison of broth microdilution and disk diffusion test for antimicrobial resistance testing in Yersinia enterocolitica 4/O:3 strains. Microb Drug Resist., 2011; 17(3): 479-484.

54. Fàbrega A, Vila J, Yersinia enterocolitica: Pathogenesis, virulence and antimicrobial resistance. Enferm Infecc Microbiol Clin., 2012; 30(1): 24-32.

55. Bolton DJ, Ivory C, McDowell D, A small study of Yersinia enterocolitica in pigs from birth to carcass and characterisation of porcine and human strains. Food Control., 2013; 33(2): 521-524.

56. Bonardi S, Bassi L, Brindani F, D'Incau M, Barco L, Carra E, Pongolini S, Prevalence, characterization and antimicrobial susceptibility of Salmonella enterica and Yersinia enterocolitica in pigs at slaughter in Italy. Int J Food Microbiol., 2013;163(2-3): 248-257.

57. Bucher M, Meyer C, Grötzbach B, Wacheck S, Stolle A, Fredriksson-Ahomaa M, Epidemiological data on pathogenic Yersinia enterocolitica in southern Germany during 2000 - 2006. Foodborne Pathog Dis., 2008; 5(3): 273-280.

58. Fredriksson-Ahomaa M, Stolle A, Stephan R, Prevalence of pathogenic Yersinia enterocolitica in pigs slaughtered at a Swiss abattoir. Int $J$ Food Microbiol., 2007; 119(3): 207-212.

59. Jamali H, Radmehr B, Ismail S, Prevalence and antimicrobial resistance of Listeria, Salmonella, and Yersinia species isolates in ducks and geese. Poult Sci., 2014; 93(4): 1023-1030.

60. Bonke R, Wacheck S, Stuber E, Meyer C, Martlbauer E, Fredriksson-Ahomaa M, Antimicrobial susceptibility and distribution of beta-lactamase A (blaA) and beta-lactamase B (blaB) genes in enteropathogenic Yersinia species. Microb Drug Resist., 2011; 17(4): 575-581.

61. Gomez-Garces JL, Wilhelmi I, Cogollos R, Alos JI, Paez M, Balas D, Arribi A. Delgado-Iribarren A, Factors of pathogenicity, biotype, serotype and antimicrobial sensitivity of 150 clinical isolates of Yersinia enterocolitica (1992-1994). Enferm Infecc Microbiol Clin., 1996; 14(10): 596-599.

62. Alzugaray R, Gonzalez Hevia MA, Landeras E, Mendoza MC, Yersinia enterocolitica O:3. Antimicrobial resistance patterns, virulence profiles and plasmids. New Microbiol., 1995; 18(2): 215-22.

63. Funk JA, Ttoutt HF, Davis SA, Fossler CP, In vitro susceptibility of Yersinia enterocolitica isolated from the oral cavity of swine. J Food Prot., 2000; 63(3): 395-399.

64. Stock I, Wiedemann B. An in vitro study of the antimicrobial susceptibilities of Yersinia enterocolitica and the definition of a database. $J$ Antimicrob Chemother., 1999; 43(1): 37-45.

65. Fredriksson-Ahomaa M, Meyer C, Bonke R, Stüber E, Wacheck S, Characterization of Yersinia enterocolitica 4/O:3 isolates from tonsils of Bavarian slaughter pigs. Lett Appl Microbiol., 2010; 50(4): 412-418. 